\title{
TINGKAT IMPLEMENTASI DAN HAMBATAN ADOPSI BUILDING INFORMATION MODELING PADA PELAKU PROYEK KONSTRUKSI DI BALI
}

\author{
I Made Agoes Megapathi ${ }^{1}$, I Gusti Agung Adnyana Putera ${ }^{2}$, Nyoman Martha Jaya ${ }^{3}$ \\ ${ }^{1,2,3}$ Program Studi Magister Teknik Sipil Universitas Udayana \\ Email: made.agoes@gmail.com
}

\begin{abstract}
ABSTRAK
Banyak negara telah menetapkan strategi implementasi untuk penggunaan BIM pada proyek konstruksi yang telah menghasilkan penyebaran lebih luas adopsi BIM. Untuk mengejar ketertinggalan Kementerian PUPR telah meluncurkan Roadmap Konstruksi Digital Indonesia 2017-2024 melalui 4 tahap, yaitu tahap Adopsi, Digitalisasi, Kolaborasi, dan Integrasi. Namun saat ini pada tahap Adopsi dari Roadmap tersebut masih difokuskan hanya pada beberapa proyek infrastruktur PUPR saja. Hal ini disebabkan oleh permasalahan seperti, belum tersedianya kebijakan dan peraturan penerapan BIM untuk seluruh sektor infrastruktur PUPR, masih kurangnya penguasaan BIM baik dari Pengguna, maupun Penyedia Jasa, belum masifnya skala proyek sehingga harga perangkat lunak BIM dirasa masih membebani Penyedia. Penelitian ini bertujuan menyelidiki penguasaan BIM tersebut melalui studi tingkat penggunaan, implementasi serta mengidentifikasi hambatan dominan pada adopsi BIM tersebut, khususnya pada pelaku proyek konstruksi di Bali. Penelitian ini diharapkan membantu praktisi industri konstruksi untuk memahami tantangan adopsi BIM di Bali. Pengumpulan data dilakukan dengan metode survei menggunakan kuesioner. Responden dipilih menggunakan metode purposive sampling, yaitu expert dalam proyek konstruksi di Bali. Metode analisis yang digunakan adalah metode statistik deskriptif, yang meliputi central tendency measurement, variability measurement, dan Relative Importance Index (RII). Hasil analisis survei dari seluruh responden menunjukkan bahwa tingkat adopsi BIM pelaku proyek konstruksi di Bali adalah 19\%. Pelaku proyek konstruksi di Bali $89 \%$ ada pada implementasi BIM tingkat 1 dan $11 \%$ ada pada implementasi BIM tingkat 2. Hambatan dominan dalam adopsi BIM adalah mahalnya biaya adopsi, kurangnya tenaga ahli, kurangnya peran pemerintah dalam mendorong adopsi BIM, kesulitan mengubah proses kerja dan belum ada standar dan protokol dalam mengaplikasikan BIM dalam proyek.
\end{abstract}

Kata kunci: Building Information Modeling, tingkat adopsi, tingkat implementasi, hambatan dominan

\section{LEVEL OF IMPLEMENTATION AND BARRIERS OF ADOPTION OF BUILDING INFORMATION MODELING ON CONSTRUCTION PROJECT ACTOR IN BALI}

\begin{abstract}
Many countries have established implementation strategies for the use of BIM in construction projects which have resulted in the widespread adoption of BIM. To catch up, the Ministry of PUPR has launched the Indonesia Digital Construction Roadmap 2017-2024 through 4 stages, namely the Adoption, Digitalization, Collaboration, and Integration stages. However, currently at the Adoption stage of the Roadmap, it is still focused on only a few PUPR infrastructure projects. This is due to problems such as the unavailability of policies and regulations for implementing BIM for the entire PUPR infrastructure sector, the lack of mastery of BIM from both Users and Service Providers, the project scale is not yet massive so that the price of BIM software is felt to be still burdening the Provider. This study aims to investigate the mastery of BIM through a study of the level of use, implementation, and identification of the dominant barriers to BIM adoption, especially for construction project actors in Bali. This research is expected to help construction industry practitioners to understand the challenges of BIM adoption in Bali. Data collection was carried out by survey method using a questionnaire. Respondents were selected using the purposive sampling method, namely experts in construction projects in Bali. The method of analysis is descriptive statistics which includes central tendency measurement, variability measurement, and the Relative Importance Index (RII). The survey results from all respondents showed that the adoption rate of BIM for construction project actors in Bali was 19\%. Level of BIM implementation of construction project actors in Bali are 89\% at BIM level 1 and $11 \%$ are at BIM level 2. The dominant obstacles in BIM adoption are the high cost of adoption, lack of experts, lack of government role in encouraging BIM adoption, difficulty changing work processes and there is no standard and protocol in applying $\mathrm{BIM}$ in the project.
\end{abstract}

Keywords: Building Information Modeling, level of adoption, BIM maturity levels, dominant barriers 


\section{PENDAHULUAN}

Layanan BIM memberikan potensi untuk memodelkan informasi virtual dalam sebuah model tunggal yang menawarkan visualisasi, deteksi benturan, fase konstruksi, dan bahan-bahan serta pengujian model untuk diserahkan oleh tim desain (arsitek, surveyor, insinyur konsultasi, dan lain-lain) kepada kontraktor dan subkontraktor dan kemudian ke pemiliknya. Hasil lainnya adalah antisipasi untuk mengurangi kehilangan informasi yang terjadi ketika sebuah tim baru mengambil alih proyek dan dalam transfer informasi yang dibutuhkan dari proyek sebelumnya. (Rayendra \& Soemardi, 2014)

Banyak negara telah menetapkan strategi implementasi untuk penggunaan BIM pada proyek konstruksi yang telah menghasilkan penyebaran luas adopsi BIM misalnya, Inggris, Amerika Serikat, Australia dan Singapura. Di Indonesia, proses adopsi teknologi BIM dapat dikatakan lebih lambat daripada negara-negara tersebut. Sebagai usaha untuk mengejar ketinggalan tersebut, pada tahun 2017 Kementerian PUPR sebagai Kementerian yang membidangi Bangunan Gedung meluncurkan Roadmap Konstruksi Digital Indonesia 2017 2024 melalui 4 tahap, yaitu tahap Adopsi, Digitalisasi, Kolaborasi, dan Integrasi. Namun pada tahap Adopsi dari Roadmap tersebut saat ini masih difokuskan hanya pada beberapa proyek infrastruktur PUPR saja. Hal ini disebabkan oleh permasalahan seperti, belum tersedianya kebijakan dan peraturan penerapan BIM untuk seluruh sektor infrastruktur PUPR, masih kurangnya penguasaan tentang penguasaan BIM baik dari Pengguna, maupun Penyedia Jasa, belum masifnya skala proyek sehingga harga perangkat lunak BIM dirasa masih membebani Penyedia. (Vaza, 2019)

Berdasarkan masalah tersebut penulis ingin menyelidiki tingkat penguasaan BIM penyedia jasa dengan mencari tingkat implementasi BIM (BIM maturity) pelaku proyek konstruksi di Bali dan mengidentifikasi hambatan (barriers) pada implementasi BIM tersebut. Penelitian ini diharapkan membantu praktisi industri konstruksi untuk memahami tantangan implementasi BIM, khususnya di Bali.

\section{ADOPSI BUILDING INFORMATION MODELING}

Menurut National BIM Standard Amerika Serikat, Building Information Model adalah "sebuah representasi digital dari karakteristik-karakteristik fisik \& fungsional dan informasi-informasi yang terkait terhadap sebuah bangunan yang menjadi dasar untuk mengambil keputusan selama siklus hidup bangunan tersebut; dari konsep awal bangunan hingga pembongkaran bangunan tersebut.” (BuildingSMART Alliance, 2007)

Teori dasar dibalik Building Information Modeling dijelaskan oleh Thompson dan Miner (2006), yaitu "Jika semua informasi yang relevan pada sebuah proyek disimpan dalam sebuah sistem daring tunggal (single online system), maka proyek tersebut dapat dieksekusi dalam lingkungan virtual terlebih dahulu. Ketika dimensi waktu (scheduling) dan biaya ditambahkan ke dalam model, hal ini akan memudahkan analisis pilihan biaya, mutu, dan waktu yang berbeda-beda hampir seketika." (Thomson \& Miner, 2006)

Setiap kali jenis informasi tertentu ditambahkan ke dalam model, dimensi (D) yang berbeda ditetapkan. Dengan menggunakan BIM dapat diperoleh 3D, 4D, 5D, 6D dan bahkan sampai 7D. Dimana 3D berbasis obyek pemodelan berparameter, 4D adalah urutan dan penjadwalan material, pekerja, luasan area, waktu, dan lain-lain, 5D termasuk estimasi biaya dan part-lists, dan 6D mempertimbangkan dampak lingkungan termasuk analisis energi dan deteksi konflik, serta 7D untuk fasilitas manajemen. (Pusdiklat Sumber Daya Air dan Konstruksi Kementrian PUPR, 2018)

Lebih jauh tingkat implementasi BIM (BIM maturity) dapat digolongkan menjadi 4 tingkat yaitu: Level 0, dimana tidak ada kolaborasi sama sekali, CAD dua dimensi digunakan untuk penggambaran dan dokumentasi (drafting). Level 1, dimana pekerjaan desain konseptual dengan model 3 dimensi, sedangkan gambar CAD dua dimensi digunakan untuk dokumentasi (drafting), pada tahap ini terdapat standar CAD dan informasi yang disepakati dan dikolaborasikan masing-masing tim disiplin dalam bentuk elektronik namun setiap disiplin memiliki standarnya sendiri-sendiri. Level 2, dimana program BIM digunakan secara kolaboratif, namun setiap disiplin menggunakan model dan objek nya sendiri-sendiri, informasi dipertukarkan dengan protokol dan format yang disetujui (IFC2 dan COBie). Dan Level 3, dimana kolaborasi penuh antar semua disiplin dan pelaku menggunakan satu objek (shared model), semua pelaku dapat mengerjakan, memodifikasi objek yang sama. Level 3 ini dikenal dengan nama OpenBIM. (Kusumartono, dkk, 2018)

Beberapa studi telah membuat kesimpulan tentang keuntungan dan manfaat yang mungkin didapat bila menggunakan BIM dibandingkan 2D CAD tradisional. Azhar (2008) mengatakan "Ketika penggunaan BIM lancar, kolaborasi di dalam tim proyek akan meningkat, yang kemudian akan meningkatkan profitabilitas, menekan biaya, manajemen waktu yang lebih baik dan meningkatkan hubungan dengan klien." (Azhar, Hein, \& Sketo, 2008).

Menurut Kiviniemi (2013), industri arsitektur, teknik bangunan dan konstruksi memiliki pengembangan produktivitas yang buruk dibandingkan dengan industri produksi yang lain, bahkan dikatakan bahwa produktivitas industri arsitektur, teknik bangunan dan konstruksi mengalami penurunan dalam 40 tahun terakhir. (Kiviniemi, 2013). Perkembangan ini berakar dari aliran informasi yang buruk dan kebutuhan akan redundansi informasi. BIM menjawab masalah-masalah itu, dengan meningkatkan manajemen informasi di dalam proyek 
konstruksi dan memungkinkan lebih banyak kolaborasi antar pihak dalam industri arsitektur, teknik bangunan dan konstruksi. Tetapi BIM sendiri bukanlah sebuah tujuan, melainkan sebuah alat untuk mencapai produktivitas yang lebih tinggi. (Eastman, Teicholz, Rafael, \& Kathleen, 2008)

Arayici, dkk. (2009) menyimpulkan "BIM dapat memberikan manfaat yang luar biasa, tetapi untuk melakukannya membutuhkan kita meninggalkan cara-cara tradisional dalam bekerja." (Arayici, Khosrowshahi, Ponting, \& Mihindu, 2009). Menurut Rayendra (2014), keuntungan dari layanan BIM adalah sebagai berikut: (Rayendra \& Soemardi, 2014)

a) Meminimalisir desain lifecycle dengan meningkatkan kolaborasi antara owner, konsultan dan kontraktor

b) Kualitas tinggi dan akurasi dokumentasi dari proses konstruksi

c) Teknologi BIM digunakan untuk siklus hidup seluruh bangunan, termasuk fasilitas operasi dan pemeliharaan

d) Produk dengan kualitas tinggi dan memperkecil kemungkinan konflik

e) Pemotongan biaya proyek dan meminimalisir limbah konstruksi

f) Meningkatkan manajemen konstruksi.

Menurut Gu dan Landon (2010) meskipun manfaat potensial BIM telah diteliti dengan baik, dalam hal produktivitas dan manfaat potensial lainnya, tingkat adopsi BIM di industri arsitektur, teknik bangunan dan konstruksi masihlah lambat. Menurut Kiviniemi (2013), alasan implementasi BIM yang lambat bukan terkait hanya pada satu isu, melainkan kombinasi dari beberapa isu. (Gu \& London, 2010) (Kiviniemi, 2013)

$\mathrm{Gu}$, dkk. (2008) menyajikan sebuah cara mengategorikan faktor-faktor yang relevan pada adopsi BIM yang lambat. Faktor-faktor yang dimaksud adalah faktor yang berkaitan dengan produk, proses dan manusia. (Gu, Singh, London, \& Taylor, 2008)

\subsection{Faktor Penghalang yang Berhubungan dengan Produk}

Banyak isu yang menghalangi adopsi BIM dalam industri Arsitektur, Teknik dan Konstruksi (ATK) berhubungan dengan program BIM dan perkembangannya. Isu-isu ini sebagian besar merupakan aspek-aspek kurangnya interoperabilitas antara berbagai program dan alat BIM, tetapi hal ini tidak hanya satu-satunya aspek yang bermasalah. Aspek lainnya adalah bahwa kebutuhan pengguna (user) tidak selalu dapat dipenuhi oleh program BIM yang sudah ada dan perbedaan pandangan tentang BIM oleh pelaku proyek konstruksi. (Gu, Singh, London, \& Taylor, 2008)

\subsection{Faktor Penghalang yang Berhubungan dengan Proses}

Menurut Gu dan London (2010) pengadopsian BIM akan memerlukan perubahan proses kerja yang telah ada selama ini. Proses bisnis yang baru ini harus diadopsi berbagai pihak yang membuat peran dan fungsi pihakpihak tersebut akan terpengaruh. Masalah hukum yang berhubungan dengan tanggung jawab dan kepemilikan dari model BIM yang dibuat adalah topik yang juga perlu diselesaikan secara efektif. (Gu, Singh, London, \& Taylor, 2008)

\subsection{Faktor Penghalang yang Berhubungan dengan Manusia}

Menurut Gu, dkk (2008), BIM dapat berhasil dalam implementasinya apabila semua pelaku industri paham akan potensi dan manfaat bagi masing-masing pihak yang terlibat. Bersamaan dengan itu, semua orang yang terlibat dengan BIM perlu memiliki keterampilan dalam penggunaannya untuk mendapatkan manfaat ini. (Gu, Singh, London, \& Taylor, 2008). Rizal (2011) menambahkan, penerapan BIM akan mempengaruhi peran dan hubungan aktor yang berpartisipasi serta proses kerja mereka. Salah satu peran baru dalam proyek konstruksi tersebut adalah manajer model BIM. (Rizal, 2011) 


\section{METODE PENELITIAN}

\subsection{Rancangan Penelitian}

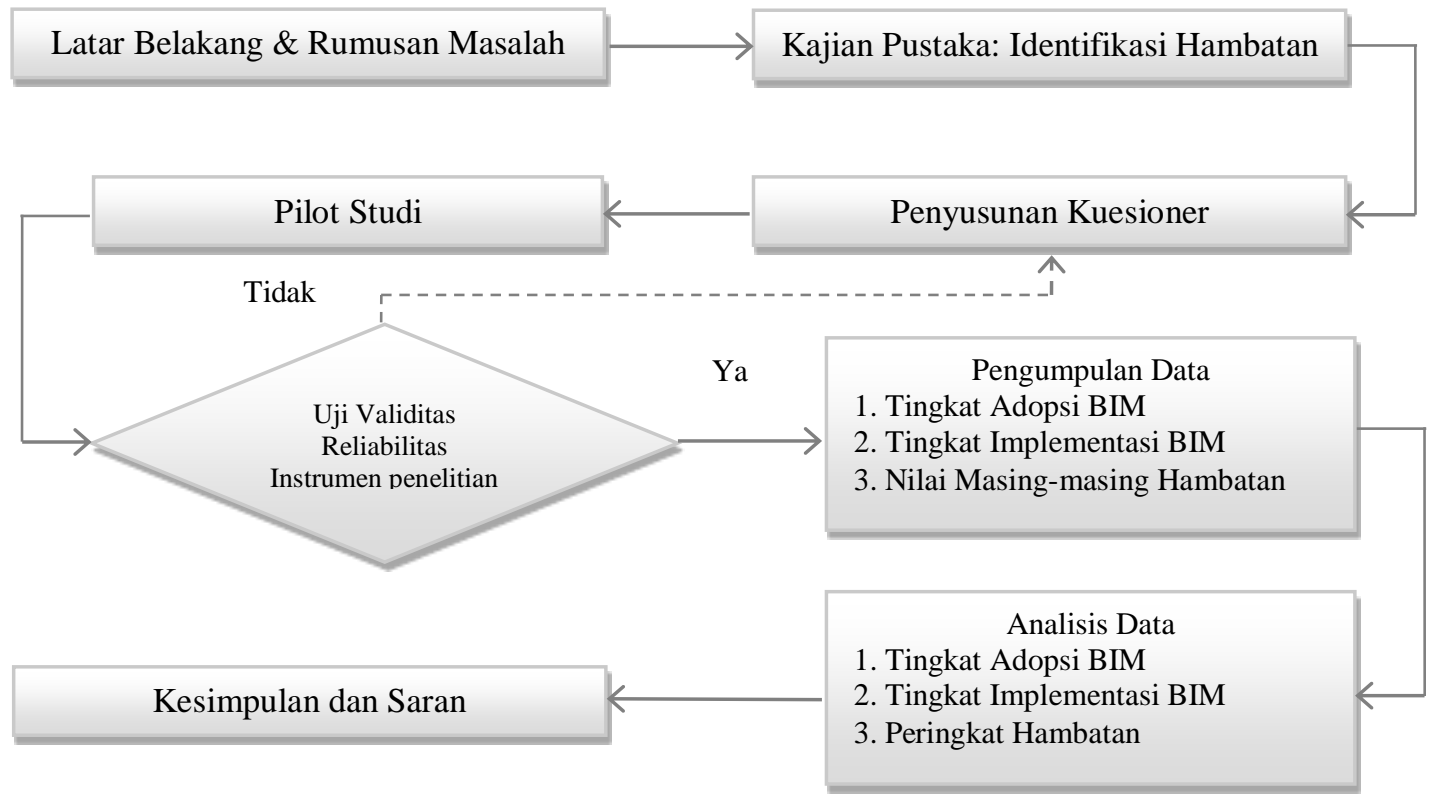

Gambar 1. Bagan Rancangan Penelitian

Identifikasi hambatan-hambatan yang berhubungan proses adopsi BIM dilakukan melalui studi literatur. Dari identifikasi ini kemudian disusun instrumen penelitian yang berupa kuesioner. Instrumen penelitian berfungsi untuk mencari tingkat adopsi dan tingkat penggunaan BIM dari responden, serta mencari frekuensi hambatan-hambatan yang sudah diperoleh dari studi literatur.

Tahap pertama dilakukan pilot survei terhadap 25 responden untuk mengecek validitas dan reliabilitas awal, jika sudah valid dan reliabel maka kuesioner akan lanjut disebar ke total responden. Dari data total yang telah valid dan reliabel akan dilakukan penilaian untuk mendapatkan kesimpulan dari faktor dominan penghambat adopsi BIM di Bali.

\subsection{Lokasi, Objek, Waktu dan Ruang Lingkup Penelitian}

Objek penelitian ini adalah profesional-profesional yang terlibat pada industri konstruksi di Bali. Termasuk di antaranya, arsitek, desainer interior, manajer proyek, insinyur lapangan, dan kontraktor. Responden dalam penelitian ini adalah para expert secara khusus yang memiliki pengalaman melaksanakan proyek konstruksi gedung dan infrastruktur, yaitu syarat tenaga ahli dengan pendidikan $\geq \mathrm{S} 1$ dengan pengalaman di atas 5 tahun.

Pengumpulan data dari literatur dilakukan pada literatur-literatur yang dipublikasikan sebelum tahun 2019. Sedangkan untuk pengumpulan data primer opini responden dilakukan pada bulan November 2019 hingga November 2020.

\subsection{Teknik Sampling Data}

Pada penelitian ini digunakan teknik sampling purposive yaitu teknik pengambilan sampel berdasarkan pertimbangan tertentu. Pengambilan sampel berdasarkan pertimbangan bila cara pengambilan sampel dilakukan sedemikian rupa, sehingga keterwakilannya ditentukan oleh peneliti berdasarkan pertimbangan orang-orang yang telah berpengalaman. Skala untuk variabel tingkat adopsi menggunakan skala pengukuran nominal, yaitu ya dan tidak. Sedangkan skala untuk variabel hambatan menggunakan skala ordinal, yaitu 1=Sangat Lemah, 2=Lemah, 3=Cukup Kuat, 4=Kuat, 5=Sangat Kuat.

\subsection{Metode Analisis Data}

Metode statistik deskriptif digunakan dalam penelitian ini untuk menganalisis data. Metode yang digunakan adalah Central Tendency Measurement (mean), Variability Measurement (standar deviasi) dan Relative Important Indeks (RII) 
Relative Important Indeks (RII) dapat ditentukan dengan rumus:

$$
R I I=\frac{5\left(n_{5}\right)+4\left(n_{4}\right)+3\left(n_{3}\right)+2\left(n_{2}\right)+1\left(n_{1}\right)}{5\left(n_{5}+n_{4}+n_{3}+n_{2}+n_{1}\right)}
$$

dimana: $\mathrm{n}_{5}=$ jumlah responden yang menjawab "Sangat Kuat"

$\mathrm{n}_{4}=$ jumlah responden yang menjawab "Kuat"

$\mathrm{n}_{3}=$ jumlah responden yang menjawab "Cukup Kuat"

$\mathrm{n}_{2}=$ jumlah responden yang menjawab "Lemah"

$\mathrm{n}_{1}=$ jumlah responden yang menjawab "Sangat Lemah"

$\mathrm{N}=$ jumlah total responden

\section{HASIL DAN PEMBAHASAN}

\subsection{Pilot Study Pertama}

Tabel 1. Hambatan adopsi BIM dari hasil studi literatur untuk pilot study pertama

\begin{tabular}{|c|c|c|}
\hline No. & Hambatan & KODE \\
\hline 1 & $\begin{array}{l}\text { Kurangnya peran pemerintah dalam mendorong adopsi BIM di kalangan } \\
\text { pelaku proyek konstruksi }\end{array}$ & HPS01 \\
\hline 2 & $\begin{array}{l}\text { Owner tidak meminta penggunaan BIM secara spesifik, sehingga tidak ada } \\
\text { motivasi untuk menggunakan BIM }\end{array}$ & HPS02 \\
\hline 3 & Kurangnya pemahaman tentang manfaat BIM & HPS03 \\
\hline 4 & Kurangnya ahli di bidang BIM & HPS04 \\
\hline 5 & Kurangnya ahli yang bisa melatih dan mengajar software BIM & HPS05 \\
\hline 6 & Kurangnya standar dan protokol dalam mengaplikasikan BIM & HPS06 \\
\hline 7 & Mahalnya biaya perangkat keras untuk menjalankan aplikasi BIM & HPS07 \\
\hline 8 & Mahalnya biaya pelatihan & HPS08 \\
\hline 9 & Mahalnya biaya perangkat lunak BIM dan biaya pembaruannya & HPS09 \\
\hline 10 & $\begin{array}{l}\text { Waktu pengaplikasian BIM yang lama dan dampaknya terhadap proyek } \\
\text { yang sedang berjalan }\end{array}$ & HPS10 \\
\hline 11 & Minimnya kompetisi dalam penggunaan BIM & HPS11 \\
\hline 12 & Kurangnya usaha yang sama antar disiplin dalam adopsi BIM & HPS12 \\
\hline 13 & Kesulitan dalam mempelajari penggunaan perangkat lunak BIM & HPS13 \\
\hline 14 & $\begin{array}{l}\text { Merasa perangkat lunak yang digunakan saat ini sudah mencukupi } \\
\text { kebutuhan }\end{array}$ & HPS14 \\
\hline 15 & $\begin{array}{l}\text { Kesulitan mengubah cara kerja, karena sudah merasa nyaman dengan } \\
\text { perangkat lunak yang digunakan selama ini }\end{array}$ & HPS15 \\
\hline 16 & Nilai investasi yang belum jelas dari pengaplikasian BIM & HPS16 \\
\hline 17 & Kurangnya interoperabilitas antar perangkat lunak BIM & HPS17 \\
\hline 18 & $\begin{array}{l}\text { Adanya risiko yang terkait dengan kekayaan intelektual dan hak cipta } \\
\text { desain }\end{array}$ & HPS18 \\
\hline 19 & Perlunya formulasi untuk membuat kontrak baru dalam menggunakan BIM & HPS19 \\
\hline 20 & Pasar yang belum siap menerima perubahan ke BIM & HPS20 \\
\hline
\end{tabular}

Dengan menggunakan program SPSS 24 dilakukan perhitungan validitas dan reliabilitas. Alpha cronbach diperoleh nilai 0,875 . Hasil ini menunjukkan kuesioner pilot study pertama dapat dikatakan reliabel karena nilai alpha cronbach > 0,7. Dari hasil perhitungan uji validitas didapatkan bahwa HPS05, HPS07, HPS08. HPS010, dan HPS11 tidak valid karena nilai $r_{\text {hitung }}<r_{\text {tabel }}$. Maka diputuskan untuk melakukan pilot study kedua dengan tidak menyertakan hambatan-hambatan yang tidak valid, dengan pertimbangan bahwa beberapa hambatan yang tidak valid dapat diwakilkan oleh hambatan yang valid. Misalnya, HPS07 dan HPS08 yang tidak valid dapat diwakilkan oleh HPS09 karena masih berhubungan dengan faktor biaya. Kemudian HPS05 yang tidak valid dapat diwakilkan dengan HPS06 karena masih berhubungan dengan tenaga ahli. Dilakukan juga perubahan redaksi faktor-faktor hambatan agar responden lebih paham dengan pertanyaan yang diajukan. 


\subsection{Pilot Study Kedua}

Tabel 2. Hambatan adopsi BIM pilot study kedua

\begin{tabular}{|c|l|l|}
\hline No. & \multicolumn{1}{|c|}{ Hambatan } & KODE \\
\hline 1 & $\begin{array}{l}\text { Kurangnya peran pemerintah dalam mendorong adopsi BIM di kalangan } \\
\text { pelaku proyek konstruksi }\end{array}$ & HB01 \\
\hline 2 & $\begin{array}{l}\text { Owner tidak meminta penggunaan BIM secara spesifik, sehingga tidak ada } \\
\text { motivasi untuk menggunakan BIM }\end{array}$ & HB02 \\
\hline 3 & $\begin{array}{l}\text { Kurangnya tenaga yang ahli di bidang BIM (pengajar dan tenaga kerja) } \\
\text { Belum paham tentang BIM dan manfaatnya dalam sebuah proyek }\end{array}$ & HB03 \\
\hline 5 & Belum ada standar dan protokol dalam mengaplikasikan BIM dalam proyek & HB05 \\
\hline 6 & $\begin{array}{l}\text { Mahalnya biaya adopsi BIM (biaya perangkat lunak, perangkat keras, dan } \\
\text { pelatihan) }\end{array}$ & HB06 \\
\hline 7 & $\begin{array}{l}\text { Kesulitan bekerja sama dengan disiplin lain, karena masih banyak yang } \\
\text { belum menggunakan BIM }\end{array}$ & HB07 \\
\hline 8 & $\begin{array}{l}\text { Minimnya kompetisi dalam penggunaan BIM } \\
\text { Kesulitan dalam mempelajari penggunaan perangkat lunak BIM }\end{array}$ & HB08 \\
\hline 10 & $\begin{array}{l}\text { Perangkat lunak yang digunakan saat ini sudah mencukupi kebutuhan } \\
\text { Kesulitan mengubah cara kerja, karena merasa sudah terbiasa dengan } \\
\text { perangkat lunak yang digunakan saat ini }\end{array}$ & HB11 \\
\hline 12 & $\begin{array}{l}\text { Nilai investasi dan profit yang belum jelas dari pengaplikasian BIM dalam } \\
\text { proyek konstruksi }\end{array}$ & HB12 \\
\hline 13 & $\begin{array}{l}\text { Ada berbagai perangkat lunak BIM yang tidak kompatibel satu sama lain } \\
\text { (masalah interoperabilitas) }\end{array}$ & HB13 \\
\hline 14 & $\begin{array}{l}\text { Adanya masalah kepemilikan kekayaan intelektual dan hak cipta disain } \\
\text { (belum ada perlindungan kepemilikan hak cipta desain digital) }\end{array}$ & HB14 \\
\hline 15 & $\begin{array}{l}\text { Belum adanya formulasi dan standar kontrak dari sebuah proyek yang } \\
\text { menggunakan BIM }\end{array}$ & HB15 \\
\hline
\end{tabular}

Dengan menggunakan program SPSS 24 kemudian dilakukan perhitungan kembali validitas dan reliabilitas. Alpha cronbach diperoleh nilai 0,884. Hasil ini menunjukkan kuesioner pilot study kedua dapat dikatakan reliabel karena nilai alpha cronbach $>0,7$. Dari hasil uji validitas didapatkan seluruh variabel mendapatkan $r_{\text {hitung }}>r_{\text {tabel }}$ sehingga dapat dikatakan valid. Maka penyebaran kuesioner dilanjutkan untuk mendapatkan jumlah minimal 100 responden.

\subsection{Profil Responden}

Dari 127 responden, 12 responden termasuk kriteria eksklusi karena tidak memenuhi syarat sebagai expert dalam bidangnya. Karakter demografi dari total 115 responden yang valid sesuai kriteria inklusi ditunjukkan pada Tabel 3 di bawah ini:

Tabel 3. Profil responden

\begin{tabular}{|c|l|c|}
\hline Kategori & \multicolumn{1}{|c|}{ Deskripsi } & Persentase \\
\hline \multirow{3}{*}{ Usia } & 20-30 tahun & $35 \%$ \\
& $31-40$ tahun & $43 \%$ \\
& $41-50$ tahun & $12 \%$ \\
& Di atas 51 tahun & $10 \%$ \\
\hline \multirow{3}{*}{ Pendidikan } & S1 & $77 \%$ \\
& S2 & $18 \%$ \\
& S3 & $5 \%$ \\
\hline \multirow{2}{*}{ Sektor } & Proyek Pemerintahan & $29 \%$ \\
Pekerjaan & Proyek Swasta & $55 \%$ \\
& Proyek Pemerintahan dan Swasta & $16 \%$ \\
\hline \multirow{3}{*}{ Spesialisasi } & Arsitek & $50 \%$ \\
Pekerjaan & Desainer Interior & $6 \%$ \\
& Insinyur Sipil & $25 \%$ \\
& Insinyur MEP & $11 \%$ \\
& Lainnya & $8 \%$ \\
\hline Peran dalam & Konsultan Perencana & $46 \%$ \\
\hline
\end{tabular}




\begin{tabular}{|c|l|c|}
\hline Proyek & Manajer Proyek & $6 \%$ \\
& Pengawas Proyek & $14 \%$ \\
& Kontraktor & $33 \%$ \\
& Lainnya & $1 \%$ \\
\hline \multirow{2}{*}{ Pengalaman } & 5-10 tahun & $33 \%$ \\
Kerja & $11-20$ tahun & $44 \%$ \\
& Lebih dari 21 tahun & $23 \%$ \\
\hline
\end{tabular}

Dari Tabel 3 profil responden di atas dapat ditarik kesimpulan, bahwa mayoritas responden berusia 31-40 tahun (43\%), pendidikannya S1 (77\%), sektor pekerjaannya proyek swasta (55\%), spesialisasi pekerjaannya arsitek (50\%), peran dalam proyek konsultan perencana (46\%) dan berpengalaman kerja 11-20 tahun (44\%)

\subsection{Pekerjaan Saat Ini dan Tingkat Implementasi BIM}

Jenis proyek yang responden kerjakan pada perusahaan tempat mereka bekerja, adalah sebagai berikut: Proyek Bangunan Gedung sebesar 68\%, Proyek Infrastruktur sebesar 18\% dan campuran (Proyek Bangunan Gedung dan Infrastruktur) sebesar 14\%.

Persentase nilai rata-rata proyek responden, yaitu: Di bawah 1 milyar $=17 \%$, satu sampai dengan 10 milyar $=51 \%$, sepuluh sampai dengan 25 milyar $=25 \%$, dan di atas 25 milyar $=7 \%$.

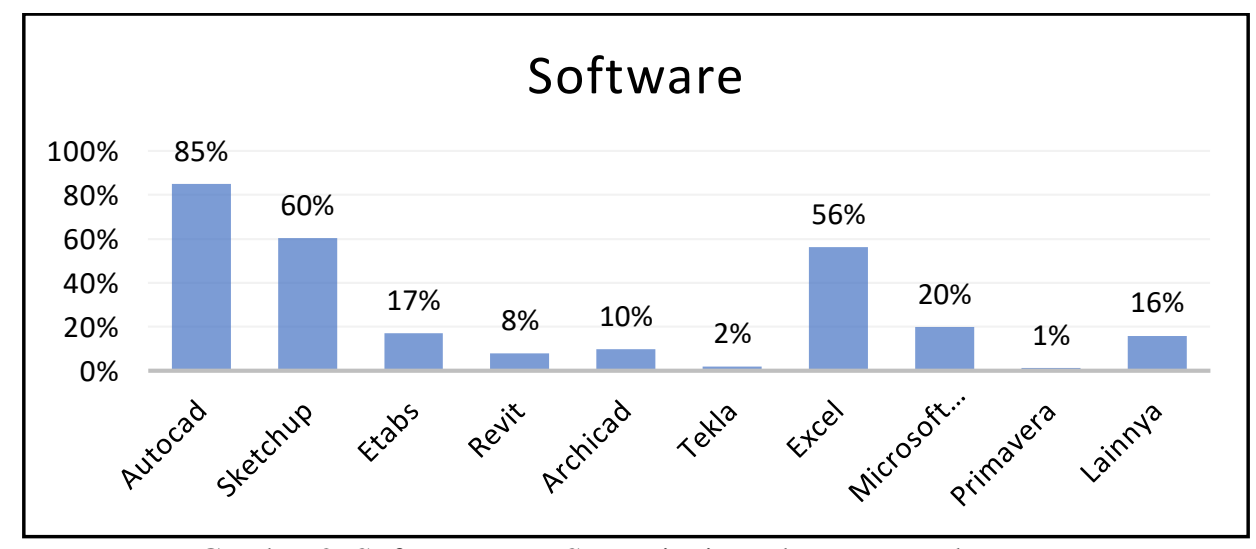

Gambar 2. Software yang Saat Ini Digunakan Responden

Persentase penggunaan perangkat lunak (software) oleh responden. Data ini menunjukkan bahwa mayoritas (94\%) responden masih menggunakan AutoCAD dalam pekerjaan mereka, perangkat lunak kedua yang paling banyak digunakan adalah Sketchup dan yang ketiga adalah Microsoft Excel.

Dari 115 responden, 22 orang menjawab YA, menggunakan software BIM di tempat kerja mereka. pada Hal ini berarti tingkat adopsi BIM di Bali adalah 19\% dari total responden. Dari hasil ini dapat dikatakan bahwa tingkat adopsi BIM di Bali masih rendah.

Dari 22 orang yang menjawab YA tersebut, 54\% menggunakan BIM hanya untuk membuat 3D model berparameter, 14\% menggunakan BIM sampai pada tahap penjadwalan (4D), 32\% menggunakan BIM sampai pada tahap estimasi biaya dan parts-list (5D) dan tidak ada yang menggunakan BIM sampai pada 6D dan 7D.

Untuk mengukur tingkat implementasi BIM (BIM Maturity Levels) responden ditanyakan bagaimana cara berkolaborasi dan berbagi informasi dengan disiplin ilmu lain yang terlibat di dalam proyek. Hasilnya adalah sebagai berikut:

Tabel 4. Tingkat Implementasi BIM Responden

\begin{tabular}{|l|l|c|}
\hline \multicolumn{1}{|c|}{ BIM Maturity Levels } & \multicolumn{1}{|c|}{ Deskripsi } & Persentase \\
\hline BIM Level 0 & Dengan berbagi dokumen cetak (hardcopy) & $0 \%$ \\
\hline BIM Level 1 & $\begin{array}{l}\text { Dengan berbagi file sesuai program yang digunakan (DWG, PDF, } \\
\text { XLSX, EDB, dll }\end{array}$ & $89 \%$ \\
\hline BIM Level 2 & Dengan berbagi file IFC dan/atau COBie & $11 \%$ \\
\hline BIM Level 3 & Dengan menggunakan satu model tunggal di cloud secara real time & $0 \%$ \\
\hline
\end{tabular}

Dari hasil ini dapat disimpulkan bahwa tingkat implementasi BIM (BIM maturity levels) pelaku proyek konstruksi di Bali mayoritas pada BIM Level 1 (89\%) dan hanya 11\% yang sudah pada BIM Level 2. 


\subsection{Hambatan Dominan}

Dari 115 responden yang valid, nilai RII masing-masing variabel dikalkulasi untuk memperoleh peringkat masing-masing variabel dibandingkan dengan variabel-variabel yang lain. Tabel 4 menunjukkan peringkat hambatan BIM telah dikalkulasi

Tabel 4. Hasil Kalkulasi Peringkat Hambatan Adopsi BIM

\begin{tabular}{|c|c|c|c|c|c|}
\hline KODE & Hambatan & Mean & SD & RII & Peringkat \\
\hline HB01 & $\begin{array}{l}\text { Kurangnya peran pemerintah dalam mendorong } \\
\text { adopsi BIM di kalangan pelaku proyek } \\
\text { konstruksi }\end{array}$ & 3,591 & 1,107 & 0,718 & 3 \\
\hline HB02 & $\begin{array}{l}\text { Owner tidak meminta penggunaan BIM secara } \\
\text { spesifik, sehingga tidak ada motivasi untuk } \\
\text { menggunakan BIM }\end{array}$ & 3,261 & 0,983 & 0,652 & 8 \\
\hline HB03 & $\begin{array}{l}\text { Kurangnya tenaga yang ahli di bidang BIM } \\
\text { (pengajar dan tenaga kerja) }\end{array}$ & 3,670 & 0,953 & 0,734 & 2 \\
\hline HB04 & $\begin{array}{l}\text { Belum paham tentang BIM dan manfaatnya } \\
\text { dalam sebuah proyek }\end{array}$ & 2,904 & 1,108 & 0,581 & 14 \\
\hline HB05 & $\begin{array}{l}\text { Belum ada standar dan protokol dalam } \\
\text { mengaplikasikan BIM dalam proyek }\end{array}$ & 3,374 & 1,063 & 0,675 & 5 \\
\hline HB06 & $\begin{array}{l}\text { Mahalnya biaya adopsi BIM (biaya perangkat } \\
\text { lunak, perangkat keras, dan pelatihan) }\end{array}$ & 3,722 & 1,113 & 0,744 & 1 \\
\hline HB07 & $\begin{array}{l}\text { Kesulitan bekerja sama dengan disiplin lain, } \\
\text { karena masih banyak yang belum menggunakan } \\
\text { BIM }\end{array}$ & 3,365 & 1,087 & 0,673 & 6 \\
\hline HB08 & Minimnya kompetisi dalam penggunaan BIM & 2,965 & 1,108 & 0,593 & 13 \\
\hline HB09 & $\begin{array}{l}\text { Kesulitan dalam mempelajari penggunaan } \\
\text { perangkat lunak BIM }\end{array}$ & 3,139 & 1,034 & 0,628 & 10 \\
\hline HB10 & $\begin{array}{l}\text { Perangkat lunak yang digunakan saat ini sudah } \\
\text { mencukupi kebutuhan }\end{array}$ & 3,296 & 1,139 & 0,659 & 7 \\
\hline HB11 & $\begin{array}{l}\text { Kesulitan mengubah cara kerja, karena merasa } \\
\text { sudah terbiasa dengan perangkat lunak yang } \\
\text { digunakan saat ini }\end{array}$ & 3,513 & 1,209 & 0,703 & 4 \\
\hline HB12 & $\begin{array}{l}\text { Nilai investasi dan profit yang belum jelas dari } \\
\text { pengaplikasian BIM dalam proyek konstruksi }\end{array}$ & 3,174 & 0,881 & 0,635 & 9 \\
\hline HB13 & $\begin{array}{l}\text { Ada berbagai perangkat lunak BIM yang tidak } \\
\text { kompatibel satu sama lain (masalah } \\
\text { interoperabilitas) }\end{array}$ & 3,026 & 0,959 & 0,605 & 11 \\
\hline HB14 & $\begin{array}{l}\text { Adanya masalah kepemilikan kekayaan } \\
\text { intelektual dan hak cipta disain (belum ada } \\
\text { perlindungan kepemilikan hak cipta desain } \\
\text { digital) }\end{array}$ & 3,000 & 0,964 & 0,600 & 12 \\
\hline HB15 & $\begin{array}{l}\text { Belum adanya formulasi dan standar kontrak } \\
\text { dari sebuah proyek yang menggunakan BIM }\end{array}$ & 2,826 & 1,028 & 0,565 & 15 \\
\hline
\end{tabular}

Hasil dari analisis menunjukkan bahwa "Mahalnya biaya adopsi BIM (biaya perangkat lunak, perangkat keras, dan pelatihan)" adalah hambatan paling dominan menurut para responden dengan nilai RII $=0,744$, ratarata $=3,722$ dan $\mathrm{SD}=1,113$. Peringkat kedua hambatan dominan adopsi BIM adalah "Kurangnya tenaga yang ahli di bidang BIM (pengajar dan tenaga kerja)" dengan $\mathrm{RII}=0,734$, rata-rata $=3,670$, dan $\mathrm{SD}=0,953$. Peringkat ketiga hambatan dominan adopsi BIM adalah "Kurangnya peran pemerintah dalam mendorong adopsi BIM di kalangan pelaku proyek konstruksi" dengan $\mathrm{RII}=0,718$, rata-rata $=3,591$ dan $\mathrm{SD}=1,107$. Peringkat keempat adalah "Kesulitan mengubah cara kerja, karena merasa sudah terbiasa dengan perangkat lunak yang digunakan saat ini" dengan $\mathrm{RII}=0,703$, rata-rata $=3,513, \mathrm{SD}=1.209$. Peringkat kelima hambatan dominan adopsi BIM adalah "Belum ada standar dan protokol dalam mengaplikasikan BIM dalam proyek" dengan RII=0,675 , ratarata=3,374, dan $\mathrm{SD}=1,063$.

\subsection{Hambatan Dominan Masing-masing Profil Responden}

Untuk mendapatkan gambaran yang lebih spesifik terhadap hasil penelitian, dilakukan analisa hambatan dominan dari masing-masing profil responden dan profil pekerjaan mereka saat ini. Tabel 5 menunjukkan hambatan dominan masing-masing profil responden. 
Tabel 5. Hambatan Dominan Masing-masing Profil Responden

\begin{tabular}{|c|c|c|c|}
\hline Kategori & Deskripsi & Persentase & Hambatan Dominan \\
\hline \multirow[t]{4}{*}{ Usia } & 20-30 tahun & $35 \%$ & HB03 \\
\hline & $31-40$ tahun & $43 \%$ & HB06 \\
\hline & $41-50$ tahun & $12 \%$ & HB06 \\
\hline & di atas 51 tahun & $10 \%$ & HB06 \\
\hline \multirow[t]{3}{*}{ Pendidikan } & S1 & $77 \%$ & HB03 \\
\hline & S2 & $18 \%$ & HB06 \\
\hline & S3 & $5 \%$ & HB01 \\
\hline \multirow[t]{3}{*}{ Sektor Pekerjaan } & Proyek Pemerintahan & $29 \%$ & HB03 \\
\hline & Proyek Swasta & $55 \%$ & HB06 \\
\hline & Proyek Pemerintahan dan Swasta & $16 \%$ & HB03 \\
\hline \multirow{5}{*}{$\begin{array}{c}\text { Spesialisasi } \\
\text { Pekerjaan }\end{array}$} & Arsitek & $50 \%$ & HB03 \\
\hline & Desainer Interior & $6 \%$ & HB01 \\
\hline & Insinyur Sipil & $25 \%$ & HB06 \\
\hline & Insinyur MEP & $11 \%$ & HB01 \\
\hline & Lainnya & $8 \%$ & HB06 \\
\hline \multirow{5}{*}{$\begin{array}{l}\text { Peran dalam } \\
\text { Proyek }\end{array}$} & Konsultan Perencana & $46 \%$ & HB06 \\
\hline & Manajer Proyek & $6 \%$ & HB06 \\
\hline & Pengawas Proyek & $14 \%$ & HB03 \\
\hline & Kontraktor & $33 \%$ & HB06 \\
\hline & Lainnya & $1 \%$ & HB06 \\
\hline \multirow[t]{3}{*}{ Pengalaman Kerja } & 5-10 tahun & $33 \%$ & HB03 \\
\hline & $11-20$ tahun & $44 \%$ & HB06 \\
\hline & lebih dari 21 tahun & $23 \%$ & HB06 \\
\hline \multirow[t]{3}{*}{ Jenis Proyek } & Bangunan Gedung & $68 \%$ & HB03 \\
\hline & Infrastruktur & $18 \%$ & HB06 \\
\hline & Bangunan Gedung dan Infrastruktur & $14 \%$ & HB06 \\
\hline \multirow[t]{4}{*}{ Nilai Proyek } & Di bawah 1 Milyar & $17 \%$ & HB06 \\
\hline & 1-10 Milyar & $51 \%$ & HB06 \\
\hline & 10-25 Milyar & $25 \%$ & HB11 \\
\hline & Di atas 25 Milyar & $7 \%$ & HB03 \\
\hline \multirow[t]{2}{*}{ Adopsi BIM } & $\mathrm{Ya}$ & $19 \%$ & HB07 \\
\hline & Tidak & $81 \%$ & HB06 \\
\hline
\end{tabular}

Tabel 5 menunjukkan bahwa 18 dari total 32 profil responden menjawab "Mahalnya biaya adopsi BIM (biaya perangkat lunak, perangkat keras, dan pelatihan)" (HB06) dan 9 profil responden menjawab "Kurangnya tenaga yang ahli di bidang BIM (pengajar dan tenaga kerja)" (HB03) sebagai hambatan dominan dalam adopsi BIM.

Tiga profil responden, seperti responden dengan Pendidikan S3, spesialisasi desainer interior, dan insinyur MEP menjawab "Kurangnya peran pemerintah dalam mendorong adopsi BIM di kalangan pelaku proyek konstruksi" (HB01) sebagai hambatan dominan; dan 1 profil responden yaitu profil dengan nilai proyek di bawah 10-25 Milyar menjawab "Kesulitan mengubah cara kerja, karena merasa sudah terbiasa dengan perangkat lunak yang digunakan saat ini” (HB11) sebagai hambatan dominan. Sedangkan profil responden yang sudah menggunakan BIM dalam pekerjaan mereka menjawab "Kesulitan bekerja sama dengan disiplin lain, karena masih banyak yang belum menggunakan BIM" (HB07) sebagai hambatan dominan.

\section{KESIMPULAN}

Berdasarkan hasil analisis data penelitian dan pembahasan atas informasi yang diberikan oleh responden maka kesimpulan dari penelitian ini adalah sebagai berikut: 
1. Tingkat adopsi Building Information Modeling pelaku proyek konstruksi di Bali adalah 19 persen. Dari 19 persen tingkat adopsi tersebut, 54 persennya menggunakan BIM sampai pada tahap 3D, 14 persen pada tahap 4D, dan 32 persen sampai pada tahap 5D.

2. Tingkat implementasi BIM (BIM Maturity Level) pelaku proyek konstruksi di Bali adalah 89 persen pada BIM level 1 dan 11 persen pada BIM level 2.

3. Hambatan dominan adopsi Building Information Modeling menurut pelaku proyek konstruksi di Bali adalah mahalnya biaya adopsi, kurangnya tenaga ahli, kurangnya peran pemerintah dalam mendorong adopsi BIM, kesulitan mengubah proses kerja dan belum ada standar dan protokol dalam mengaplikasikan BIM dalam proyek.

4. Delapan belas dari total 32 profil pelaku proyek konstruksi di Bali menjawab "Mahalnya biaya adopsi BIM (biaya perangkat lunak, perangkat keras, dan pelatihan)" (HB06) dan 9 profil pelaku proyek konstruksi di Bali menjawab "Kurangnya tenaga yang ahli di bidang BIM (pengajar dan tenaga kerja)" (HB03) sebagai hambatan dominan dalam adopsi BIM. Tiga profil pelaku proyek konstruksi di Bali, yaitu pelaku proyek konstruksi di Bali dengan Pendidikan S3, spesialisasi desainer interior, dan insinyur MEP menjawab "Kurangnya peran pemerintah dalam mendorong adopsi BIM di kalangan pelaku proyek konstruksi" (HB01) sebagai hambatan dominan; dan satu profil pelaku proyek konstruksi di Bali yaitu profil dengan nilai proyek di bawah 10-25 Milyar menjawab "Kesulitan mengubah cara kerja, karena merasa sudah terbiasa dengan perangkat lunak yang digunakan saat ini" (HB11) sebagai hambatan dominan. Sedangkan profil pelaku proyek konstruksi di Bali yang sudah menggunakan BIM dalam pekerjaan mereka menjawab "Kesulitan bekerja sama dengan disiplin lain, karena masih banyak yang belum menggunakan BIM” (HB07) sebagai hambatan dominan.

Dari kesimpulan yang telah didapat, penulis menyarankan:

1. Untuk penelitian selanjutnya, agar dilakukan pengambilan sampel yang lebih besar untuk mendapatkan gambaran yang lebih menyeluruh terhadap kondisi adopsi BIM di Indonesia.

2. Untuk developer perangkat lunak BIM, perlu dipikirkan skema baru pembiayaan perangkat lunak untuk menurunkan hambatan adopsi BIM karena masalah biaya, sehingga mempercepat adopsi BIM oleh pelaku proyek konstruksi di Bali

3. Untuk stakeholder asosiasi keahlian jasa konstruksi, perlu ditambahkan kurikulum baru tentang Building Information Modeling sebagai syarat sertifikasi keahlian jasa konstruksi untuk meningkatkan mempercepat adopsi BIM dan meningkatkan kualitas pelaku proyek konstruksi di Bali.

4. Untuk pemerintah, perlu dibuat program nasional dan standar protokol yang mendetail tentang penggunaan BIM dalam proyek konstruksi, khususnya pada proyek pemerintah, untuk mempercepat proses adopsi BIM oleh pelaku proyek konstruksi di Bali.

\section{DAFTAR PUSTAKA}

Arayici, Y., Khosrowshahi, F., Ponting, A., \& Mihindu, S. (2009). Towards Implementation of Building Information Modelling in the Construction Industry. Collaboration and Integration in Engineering, Management and Technology. Istanbul: Fifth International Conference on Construction in the 21th Century (CITC-V).

Azhar, S., Hein, M., \& Sketo, B. (2008). Building Information Modeling (BIM): Trends, Benefits, Risks, and Challenges for the AEC Industry. 44th ASC Annual Conference (on CD ROM). Auburn, Alabama.

BuildingSMART Alliance. (2007). National BIM Standard - United States V1 P1. National Institute of Building Sciences.

Eastman, C., Teicholz, P., Rafael, S., \& Kathleen, L. (2008). BIM Handbook: A Guide to Building Information Modeling for Owners, Managers, Designers, Engineers and Contractors. Wiley Publishing.

Gu, N., \& London, K. (2010). Understanding and Facilitating BIM Adoption in the AEC industry. Automation in Construction, 19(8), 988-999.

Gu, N., Singh, V., London, K., \& Taylor, C. (2008). BIM: Expectations and a Reality Check. 12th International Conference on Computing in Civil and Building Engineering \& 2008 International Conference on Information Technology in Construction. Beijing: Tsinghua University Press.

Kiviniemi, A. (2013). Public Clients as the Driver for BIM Adoption - Why and how UK Government wants to change the construction industry? Confrence at Clareon Hotel Arlanda. Swedia: Open BIM.

Kusumartono, dkk, F. H. (2018). Panduan Adopsi BIM dalam Organisasi. Jakarta: Pusat Litbang Kebijakan dan Penerapan Teknologi, Kementrian PUPR.

Pusdiklat Sumber Daya Air dan Konstruksi Kementrian PUPR. (2018). Modul 5: Pemodelan 3D, 4D, 5D, 6D dan 7D serta Simulasinya dan Level of Development (LoD). Jakarta: Kementrian Pekerjaan Umum dan Perumahan Rakyat. 
Rayendra, \& Soemardi, B. (2014). Studi Aplikasi Teknologi Building Information Modeling untuk PraKonstruksi. Simposium Nasional RAPI XIII. Surakarta: Fakultas Teknik Universitas Muhammadiyah Surakarta.

Rizal, S. (2011). Changing roles of the clients, architects and contractors through BIM. Engineering, Construction and Architectural Management, 18(2), 176-187.

Thomson, D., \& Miner, R. (2006). Building Information Modeling-BIM: Contractual Risks are Changing with Technology. FWHT - Construction Law Briefing Paper.

Vaza, H. (2019). Rencana Pengembangan Nasional Roadmap BIM di Indonesia. BIM National Strategy Workshop. Jakarta: Kementrian Pekerjaan Umum dan Perumahan Rakyat. 